\title{
Xeroderma Pigmentosa: High Risk for Ocular Neoplasia
}

\author{
Amr I. Elawamry1, Ahmed M. El-Moatassem Kotb1,2, Sameh Hany1 \\ ${ }^{1}$ Ain-Shams University Hospitals, Cairo, Egypt \\ ${ }^{2}$ Ophthalmology Consultant British Lasik and Cosmetic Surgery Center, Dubai, UAE \\ Email: ahmedelmotasem@yahoo.com
}

Received 1 September 2014; revised 21 September2014; accepted 29 October 2014

Copyright (C) 2014 by authors and Scientific Research Publishing Inc.

This work is licensed under the Creative Commons Attribution International License (CC BY). http://creativecommons.org/licenses/by/4.0/

(c) (i) Open Access

\begin{abstract}
Aim of Work: The aim of our work was early cytological and laboratory detection of any ocular surface malignant changes in xeroderma pigmentosa. Patients and Methods: Eighteen cases with xeroderma pigmentosa were included in this study. All cases were subjected to full ophthalmological examination, conjunctival biopsy from any abnormal lesion, polymerase chain reaction assay and impression cytology. Results: All cases were boys; the mean age was 11 years old. The main ocular presentation was dryness and abnormal epibulbar masses in different locations. Polymerase chain reaction represents precipitation of malignant cells which was confirmed by impression cytology. Conclusion: PCR and impression cytology are beneficial investigations for detection of any malignant changes in xeroderma pigmentosa.
\end{abstract}

\section{Keywords}

\section{Xeroderma Pigmentosa, Neoplasia, Early Detection}

\section{Introduction}

Patients with xeroderma pigmentosa experience cutaneous and ocular abnormalities, including the development of neoplasia. The ocular tissues affected in xeroderma pigmentosa include ocular and periocular tissues exposed to ultra violet light rays of sun [1].

Impression cytology is a non-invasive technique for obtaining superficial sheets of cells from the ocular surfaces using Millipore filter paper [2].

Polymerase chain reaction (PCR) assay was first applied in basic science but has rapidly entered into all areas of clinical medicine. PCR is beneficial in diagnosis of infectious diseases and detecting the type of the causative organism and in detecting malignant cells [3]. 
The aim of our study was to evaluate the effectiveness of PCR and impression cytology in accurate and early diagnosis of malignant changes among ocular surfaces in xeroderma pigmentosa.

\section{Patients and Methods}

Eighteen cases diagnosed as xeroderma pigmentosa were included in this study. All cases were presented with different types of epibulbar masses of abnormal nature.

Full ophthalmological examination was done including best corrected visual acuity, slit-lamp examination of the external ocular surface and anterior segment of the eye. Also measurement of intraocular tension was done.

Conjunctival impression cytology using Millipore filter paper 0.025 um pore size on different conjunctival sites, corneal and from the epibulbar lesion was done. The rough surface of the filter paper was the one used to allow picking-up of more sheets of cells in order to study the cellular morphology, cell to cell relationship and cytological abnormalities.

The samples were done by pressing a small cutted part of filter paper against the ocular surface, and then removed carefully using a non-toothed forceps to avoid ocular surface tearing. The samples were placed in ethanol $70 \%$ until laboratory examination with high-magnification light microscopy after staining with heamatoxylin and eosin using also papanicolou stain and periodic acid Schiff.

PCR assay was done using universal primer to detect malignant cells. Amplification was done with a real time PCR system and using the following parameters; determination at $94^{\circ} \mathrm{C}$ for $5 \mathrm{~min}$, followed by annealing at $55^{\circ} \mathrm{C}$ for $40 \mathrm{~s}$, extension at $72^{\circ} \mathrm{C}$ for $90 \mathrm{~s}$, and a final extension step at $72^{\circ} \mathrm{C}$ for 15 minutes [4]. Visualization of the PCR product was done using $2 \%$ agarose gel incorporating $0.5 \mathrm{ug} / \mathrm{mL}$ ethidium bromide. The gel was examined on an ultraviolet transilluminator and photographed. All data were recorded.

\section{Results}

Eighteen boys diagnosed as xeroderma pigmentosa were included in this study.

The mean age was 11 years, the age ranged from 8 - 15 years old with positive family history in all our cases.

All cases were presented with ocular swelling or mass in different regions. Nine cases were presented with unilateral recurrent temporal ptergium-like lesion, three cases were presented with nasal epibulbar pigmented mass, five cases were presented with bilateral, and multiple marginal eye lid masses characterized by marked superficial vascularization. One case only was presented with unilateral lower forniceal swelling.

All masses and swelling were increasing in size progressively with superficial vascularization. All masses were tender, firm in consistency and opaque in appearance.

The main complaint was photophobia with excessive lacrimation and cosmetic disfigurement due to the epibulbar masses in all our cases. Pain, defective vision and redness were reported in the three cases presented with the pigmented nasal epibulbar mass.

Mean best corrected visual acuity was 6/36 in most of our cases. Intraocular pressure was slightly elevated in the nine cases with the temporal pterygium-like lesions, with the mean value $=24 \mathrm{mmHg}$. Mild flare and cells was present in only one case. Eyelid skin examination revealed mottled pigmentation characteristics of xeroderma pigmentosa.

Impression cytology was done from the abnormal masses or swelling and adjacent ocular surface areas. The cytological samples revealed the presence of malignant changes in the form of nuclear fragmentation and cytoplasmic abnormal filaments from the abnormal masses (Figure 1). Squamous metaplasia was noticed in all other samples. Grade IV (Figure 2) was the dominant metaplasia in almost all our cases, which denoting marked dryness.

PCR assay showed the presence of malignant cells. The sensitivity of PCR assay was found to be highly significant $(\mathrm{P}<0.0001)$. Thus we concluded that full ophthalmological examination, impression cytology and PCR assay in any epibulbar masses is mandatory in cases of xeroderma pigmentosa.

\section{Discussion}

Xeroderma pigmentosa is an autosomal recessive disease, the heterozygous parents are clinically normal and both sexes are equally affected. Xeroderma pigmentosa characterized by defective DNA repair leading to clinical and cellular hyper-sensitivity to ultraviolet radiation. Retention of this damaged DNA leads to heritable chromosomal mutations and cell death which possibly cause neoplastic and atrophic clinical abnormalities in 


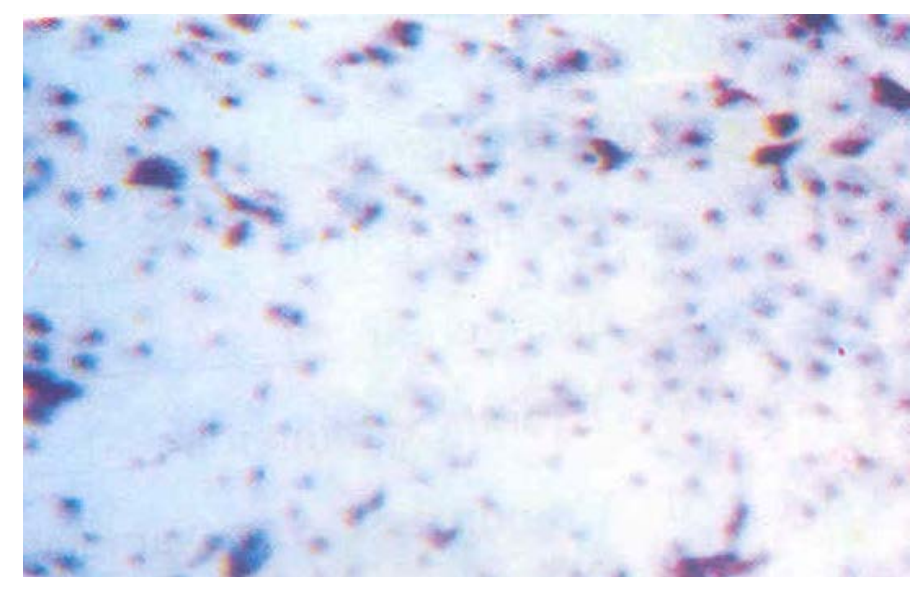

Figure 1. Presence of abnormal filaments and pigmentations.
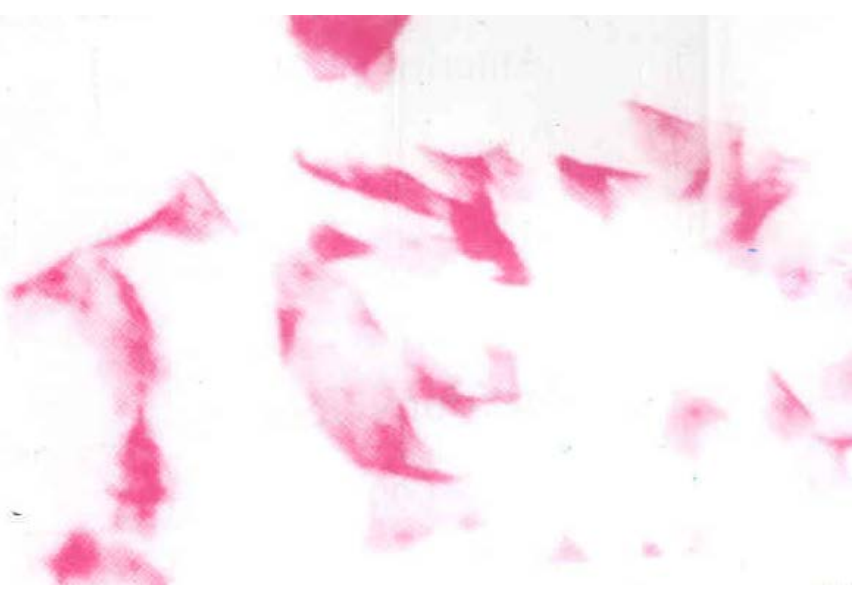

Figure 2. Enlargement cells with loss of cell-cell relation-ship (premalignant changes).

xeroderma pigmentosa [5].

The aim of this work was to discover early and accurately any malignant changes in associated epibulbar masses with the aid of impression cytology and PCR assay. Eighteen boys diagnosed as xeroderma pigmentosa were included in this study. Epibulbar swelling was the most common presentation among all our cases. The mean age was 11 years old.

Babar study included 36 eyes with xeroderma pigmentosa with biopsy proven ocular surface neoplasia [6]. In our study, impression cytology and PCR assay were the toold used for early detection of any malignant changes. In agreement with Ghobrial (2005) ocular malignant neoplasms in xeroderma pigmentosa may precede prominent skin changes [1]. Ophthalmic complications of xeroderma pigmentosa were confined to the lids, conjunctiva and the cornea.

According to our knowledge, no previous study detects malignant cells in epibulbar masses in xeroderma pigmentosa using PCR assay as in our study.

\section{Conclusion}

In conclusion impression cytology and PCR assay are very beneficial tools in detection of early malignancy in xeroderma pigmentosa.

\section{References}

[1] Ghobrial, F.G. (2005) Conjunctival Squamous Cell Carcinoma in Xeroderma PIgmentosum Case Report. Egyptian 
Bullitien of Opthalmology, 98, 18.

[2] Tseng, S.C.G. (1985) Staging of Conjunctival Squamous Metaplasiil by Impression Cytology. Ophthalmology, 92, 728-733. http://dx.doi.org/10.1016/S0161-6420(85)33967-2

[3] Ferrer, C., Colom, F., Frases, S., Mulet, E., Abad, J.L. and Alio, J.L. (2001) Detection and Identification of Fungal Pathogens by PCR and by ITS2 and 58s Ribosomal DNA Typing in Ocular Infections. Journal of Clinical Microbiology, 39, 2873-2879. http://dx.doi.org/10.1128/JCM.39.8.2873-2879.2001

[4] Lohamann, C.P., Linde, H.I. and Reisehl, U. (2000) Improved Detection of Microorganisms by Polymerase Chain Reaction in Delayed Endophthalmitis after Cataract Surgery. Ophthalmology, 107, 1047-1052. http://dx.doi.org/10.1016/S0161-6420(00)00083-X

[5] Goyal, J., Rao, V., Srinivasan, R. and Agarawal, K. (1994) Oculocutaneuos Manifestations in Xeroderma Pigmentosum. British Journal of Ophthalmology, 78, 295-297. http://dx.doi.org/10.1136/bjo.78.4.295

[6] Babar, T.F., Khan, M.N., Hussain, M., Shah, S.A., Khan, M.Y. and Khan, M.D. (2007) Spectrum of Ocular Surface Squamous Neoplasia. Journal of the College of Physicians and Surgeons Pakistan, 17, 344-346. 
Scientific Research Publishing (SCIRP) is one of the largest Open Access journal publishers. It is currently publishing more than 200 open access, online, peer-reviewed journals covering a wide range of academic disciplines. SCIRP serves the worldwide academic communities and contributes to the progress and application of science with its publication.

Other selected journals from SCIRP are listed as below. Submit your manuscript to us via either submit@scirp.org or Online Submission Portal.
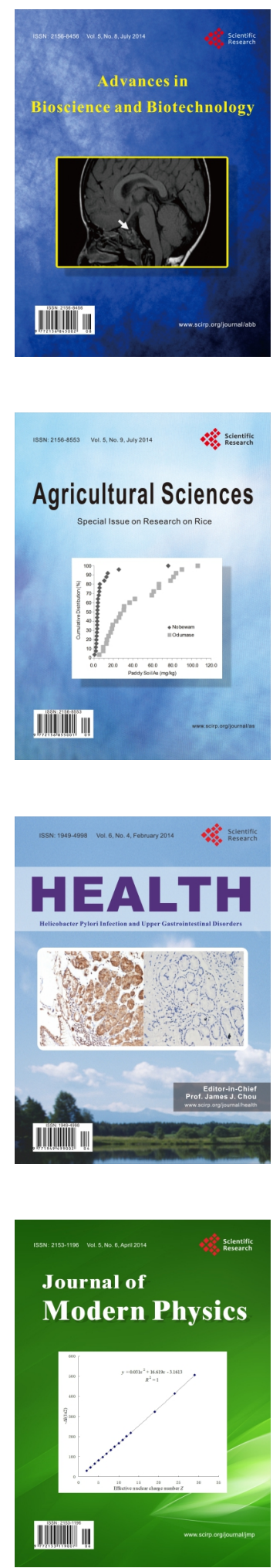
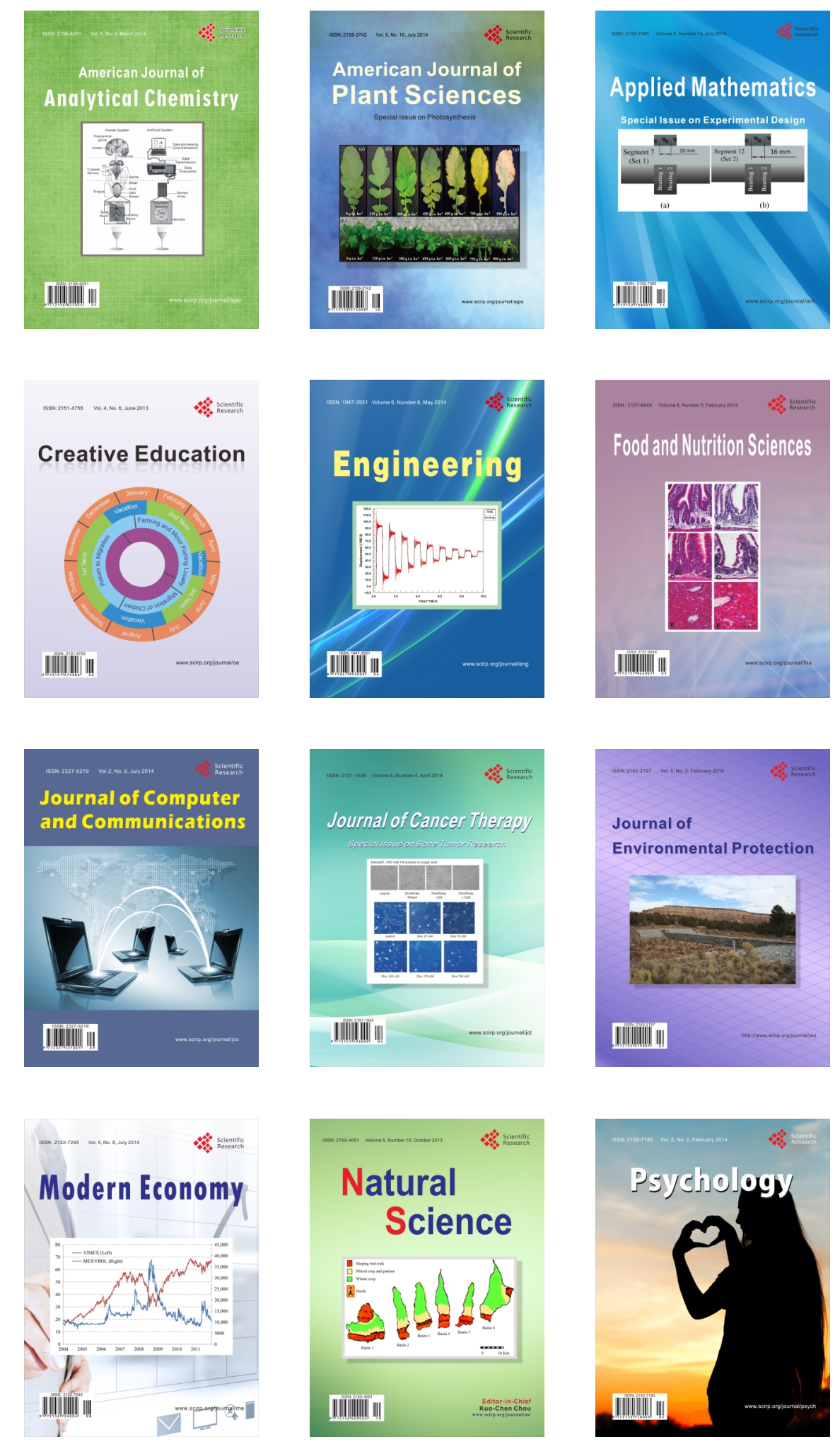